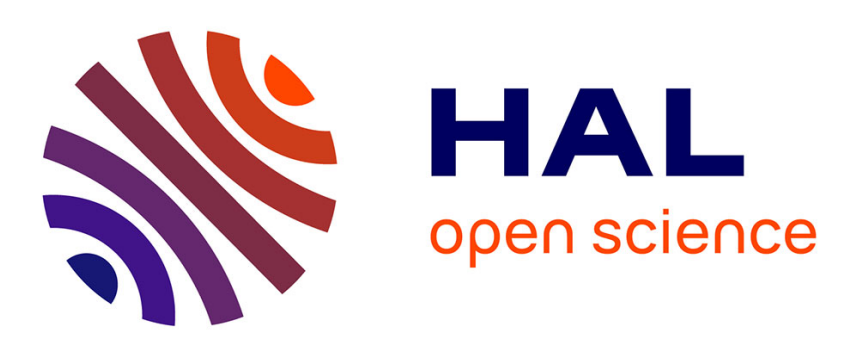

\title{
Convective Precipitation in complex terrain: Results of the COPS campaign
}

Andreas Behrendt, Alan Blyth, Manfred Dorninger, Norbert Kalthoff, Cyrille Flamant, Paolo Di Girolamo, Evelyne Richard

\section{- To cite this version:}

Andreas Behrendt, Alan Blyth, Manfred Dorninger, Norbert Kalthoff, Cyrille Flamant, et al.. Convective Precipitation in complex terrain: Results of the COPS campaign. Meteorologische Zeitschrift, 2013, 22 (4), pp.367-372. 10.1127/0941-2948/2013/0541 . hal-00923708

\section{HAL Id: hal-00923708 \\ https://hal.science/hal-00923708}

Submitted on 26 Jul 2017

HAL is a multi-disciplinary open access archive for the deposit and dissemination of scientific research documents, whether they are published or not. The documents may come from teaching and research institutions in France or abroad, or from public or private research centers.
L'archive ouverte pluridisciplinaire HAL, est destinée au dépôt et à la diffusion de documents scientifiques de niveau recherche, publiés ou non, émanant des établissements d'enseignement et de recherche français ou étrangers, des laboratoires publics ou privés. 


\title{
Convective Precipitation in complex terrain: Results of the COPS campaign
}

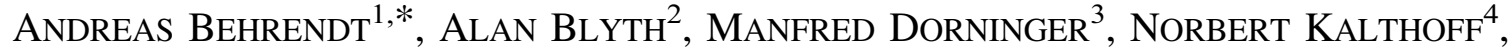 \\ Cyrille Flamant $^{5}$, PAOlo Di Girolamo ${ }^{6}$ and Evelyne Richard ${ }^{7}$ \\ ${ }^{1}$ Universität Hohenheim, Institut für Physik und Meteorologie, Stuttgart, Germany \\ ${ }^{2}$ National Centre for Atmospheric Science, University of Leeds, UK \\ ${ }^{3}$ Department of Meteorology and Geophysics, University of Vienna, Austria \\ ${ }^{4}$ Institut für Meteorologie und Klimaforschung, Karlsruher Institut für Technologie (KIT), \\ Eggenstein-Leopoldshafen, Germany \\ ${ }^{5}$ Laboratoire Atmosphères, Milieux, Observations Spatiales, CNRS/UPMC/UVSQ, Paris, France \\ ${ }^{6}$ Scuola di Ingegneria, Università degli Studi della Basilicata, Potenza, Italy \\ ${ }^{7}$ Laboratoire d'Aerologie, Toulouse, France
}

This special issue contains nine papers presenting results of the Convective and Orographically-induced Precipitation Study (COPS). The goal of COPS was to determine the physical processes responsible for the production of convective precipitation in complex terrain including heavy precipitation leading to flash flooding. COPS took place in a medium-high mountainous area covering the Black Forest and Vosges mountains in Germany and France as well as the Rhine Valley between the two ranges. The field phase of this experiment was from 1 June to 30 August 2007 with 18 intensive observation periods covering about 30 days in total (WULFMEYER and BEHRENDT, 2007; WULFMEYER et al., 2008; RICHARD et al., 2009; WULFMEYER et al., 2011).

During COPS, scientists from many European countries and the US brought together a large number of research instruments in order to investigate the process chain related to convective precipitation: synergetic remote-sensing instruments such as water vapor, temperature, and wind lidars, cloud radars, polarization weather radars, microwave radiometers, and sodars, as well as intensified networks of meteorological instruments at the ground including automatic weather stations, energy balance stations, soil moisture sensors and GPS receivers. In addition, several aircraft and a large number of radiosonde sounding systems were used to collect high-resolution in-situ data at higher altitudes. Some of the instruments and measurement techniques were new and employed during COPS for the first time (e.g., AOSHIMA et al., 2008; RADLACH et al., 2008; BEHRENDT et al., 2009; BEHRENDT et al., 2011; CORSMEIER et al., 2011; KIEMLE et al., 2011; WAGNER et al., 2013). COPS was acknowledged as a Research and Development Project of the World Weather Research Programme (WWRP) of the World Meteorological Organization (WMO). In parallel to the COPS field campaign, a suite of mesoscale numerical weather prediction models was operated in real-time within the WMO Forecast Demonstration Project D-PHASE (Demonstration of Probabilistic Hydrological and Atmospheric Simulation of flood Events in the Alpine region, see ROTACH et al., 2009a,b). The output of these models were used on the one hand for planning and refining the experimental activities. On the other hand the dense meteorological data collected during COPS could be used to verify the model performances (e.g., DORNINGER and GORGAS, 2010; BAUER et al., 2011a; HEROLD et al., 2011; CHABOUREAU et al., 2011; GORGAS and DORNINGER, 2012a,b). Furthermore, COPS was embedded in a 12-month long measurement phase which collected operational data within central Europe, the so-called General Observation Period (CREWELL et al., 2008). After the campaign, the data analysis continued, the data were quality controlled (e.g., BHAWAR et al., 2011), atmospheric processes were analyzed in detail within case studies (e.g., KOTTMEIER et al., 2008; KALTHOFF et al., 2009; BEHRENDT et al., 2011; BENNETT et al., 2011; CORSMEIER et al., 2011; HAGEN et al., 2011; HUANG et al., 2011; RICHARD et al., 2011), climatologies on convection initiation were derived (e.g., AOSHIMA et al., 2008; WECKWERTH et al., 2011) and data assimilation studies were performed (e.g., ZUS et al., 2008; YAN et al., 2009; BAUER et al., 2011b; SCHWITALLA et al., 2011;

\footnotetext{
${ }^{*}$ Corresponding author: Dr. Andreas Behrendt, Universität Hohenheim, Institut für Physik und Meteorologie, Garbenstrasse 30, 70599 Stuttgart, Germany, e-mail: andreas.behrendt@uni-hohenheim.de
} 
BIELLI et al., 2012). Even six years after the field phase of COPS, the use of COPS data is not over; most research funding related directly to COPS has finished, but the collected data still offers unique opportunities and are available for all interested scientists in well defined data formats at a data base at the World Data Center for Climate (WDCC, see $\mathrm{http} / / / \mathrm{www} . \mathrm{dkrz} . \mathrm{de} / \mathrm{daten}-\mathrm{en} / \mathrm{wdcc} /$ projects_cooperations/cops-campaign).

This special issue is now the third mayor collection containing COPS publications. In 2008, a special issue of the priority program 1167 on quantitative precipitation forecast of Deutsche Forschungsgemeinschaft (HENSE and WULFMEYER, 2008), in which COPS was embedded, contained papers already presenting first COPS results (http://www.schweizerbart.de/papers/metz/list/17\#issue6). In 2011, a special issue of the Quarterly Journal of the Royal Meteorological Society collected 21 papers (http://onlinelibrary.wiley.com/doi/10.1002/qj.v137.1s/issuetoc). In the following, we will give an overview of the papers of this special issue. Some results were not ready in time to be included in this issue, but await publication in Meteorologische Zeitschrift in forthcoming issues.

M. DORNINGER and T. GORGAS (2013) perform a model inter-comparison for model chains by using novel verification tools. They used surface parameters for the model inter-comparison which are provided by the verification tool Vienna Enhanced Resolution Analysis (VERA) and which are NWP-model independent. The observational data and model data cover the area of Central Europe and were collected in a combined effort of the projects COPS and D-PHASE. So, the verification periods allow ranging from single case studies to half a year. Due to the focus of the project, the verification parameters are precipitation and the gradient of equivalent potential temperature as front indicator. The authors could only partly confirm previous findings that the models with the highest resolution usually outperform their counterparts of lower resolution. Instead, they found a very different picture dependent from the model chain and from the used verification measure, e.g. additional forecast skill is not consistently added by the nested models with the highest resolution. In the case of frontal propagation it is the coarsest model that shows the best results.

The paper by C. PLANCHE et al. (2013) describes several model simulations of summertime precipitating convective systems, which are performed to better understand the role of orography in triggering convection in the COPS area. The research effort focuses on three case studies: July 18, August 12 and August 13, 2007. A nesting procedure focusing on the Vosges area is used to represent the synoptic influences and reproduce the small scale orography features with higher accuracy. The three simulated cases are found to compare well with available observations of local thermo-dynamical conditions, namely, high resolution X-band radar reflectivity, Vienna Enhanced Resolution Analysis (VERA) of the surface horizontal wind, and water vapour retrieval through GPS tomography. Model results and observations confirm that the convection generation is largely influenced by the Vosges' topography.

L. LABBOUZ et al. (2013) combine radar observations, surface analyses, GPS retrievals and model output to elucidate the physical processes which lead to the initiation and development of convection on the lee side of the Vosges on July 18, 2007. It is concluded that convection was initiated by the convergence of moist air flowing down the lee-side of the Vosges, in particular being funnelled down the valleys, with upslope flow coming from the Rhine. The results also suggest the important role of small hills at the exit of the valley enhancing the convergence and lifting. This work illustrates in more detail the role of water vapour as precursor to convective initiation as previously shown in VAN BAELEN et al. (2011) together with the prominent contribution of low-level convective lines to convection triggering as also observed in many other case studies (e.g. KALTHOFF et al., 2009, and BEHRENDT et al., 2011).

R. BURTON et al. (2013) extend the studies on the most-discussed COPS case so far: On July 15, 2007, a deep-convective cloud developed locally over the Black Forest. Previous studies have already discussed the COPS observations (AOSHIMA et al., 2008; KOTTMEIER et al., 2008; KALTHOFF et al., 2009; BEHRENDT et al., 2011) and related modeling efforts of this case (BARTHLOTT et al., 2009, BARTHLOTT et al., 2011, RICHARD et al., 2011). In the present study, the authors confirm that a reservoir of moist air developed on this day which provided the required conditions for convective-available potential energy to be released when a convergence zone acted as trigger for convection initiation. The authors employ a series of tests of the Weather Research and Forecasting (WRF) model to investigate the sensitivities to boundary-layer and land-surface specification in the model and show which combinations provides the required reservoir of moist air.

N. KALTHOFF et al. (2013) use synergetic data from COPS Supersite H instruments on the mountain peak Hornisgrinde in the Northern Black Forest to investigate turbulence characteristics of the convective boundary layer (CBL) over complex terrain. The combined use of different monitoring systems allowed for investigating the structure of the convective cells on three days, namely, July 14, 15, and 30,2007. The authors find significant differences between cloud-free and cloud-topped cases. Active CBL clouds penetrated deeper into the free troposphere than dry convective cells. In the cloud-free CBL, the variance of the vertical velocity decreased to zero at the CBL top; in cases of the cloud-topped CBL, the variance of the vertical velocity, however, was nearly constant in the upper half of the CBL. The higher values in cloudy cases may be explained with the additional elevated heat source due to condensation. In the cloud-free CBL, the latent heat flux profile showed a strong decrease in the upper part of the CBL and in the entrainment zone which means that these heights became considerably moistened. In the cloud-topped $\mathrm{CBL}$, the latent heat flux decreased only significantly above the CBL top when using the aerosol gradient to determine 
the CBL top height. CBL height calculations, which took measures of the turbulence into account, however, resulted in profiles, which became zero at the CBL top and appear therefore more appropriate for CBL height scaling.

J. DAVIES et al. (2013) discuss measurements performed mainly with a scanning Doppler lidar at COPS supersite $\mathrm{R}$ in the Rhine valley. Profiles of horizontal wind velocity derived from azimuth scan as well as profiles of vertical velocity, its variance and skewness derived from vertical-pointing measurements are presented and discussed. Vertical velocity skewness provides a measure of the asymmetry in the distribution of vertical velocity perturbations and is important for the understanding of the structure and origin of turbulent convection in the atmospheric boundary layer. Data of August 6, 2007 are selected for investigations of possible causes of layers with positive and negative velocity skewness. Comparisons with output from the Weather Research and Forecasting (WRF) model are shown to assess the accuracy of the model output, including location and timing of rainfall onset.

Accurate high-resolution global-coverage of water vapour fields is a key ingredient for understanding not only weather processes on the convective scale but also for climate studies. The Infrared Atmospheric Sounding Interfereometer (IASI) is one of the most advanced instruments in space to characterize the atmospheric moisture field. G. MASIELLO et al. (2013) present their work on comparison of IASI water vapour products over complex terrain to COPS campaign data. Satellite-derived profiles of water vapour mixing ratio profiles and integrated water vapour content are evaluated using GPS, radiosoundings and lidar data. The authors use two different algorithms to derive the IASI products relying on very different background vector and covariance fields. Depending on the background, they show that infrared observations of high spectral resolution can resolve dry layers in the troposphere of $\sim 1.5$ to $2 \mathrm{~km}$ thickness. Furthermore, the comparison with GPS tomography reveals that IASI retrieval accuracy is within $10 \%$ in the lower troposphere and in layers of $2 \mathrm{~km}$ thickness.

S. KHODAYAR et al. (2013) and S. KHODAYAR and G. SCHÄDLER (2013) discuss in two papers land surface processes and their representation in regional climate models and focus especially on the impact of soil moisture variability on summer-season simulations of convective precipitation. While part 1 of the two papers deals with validation, feedbacks, and realistic initialization, part 2 presents results of sensitivity studies to land-surface models and prescribed soil type distributions. The authors use the COSMO-CLM model and observations from COPS, especially, from the soil-moisture-monitoring network and surface energy balance network (see also EIGENMANN et al., 2011; HAUCK et al., 2011; KALTHOFF et al., 2011). In part 1, KHODAYAR et al. show that the simulated precipitation is overestimated by the model mainly in the valley and at lower altitudes. Interestingly, the analysis of the soil moisture distribution revealed a major underestimation in the valley and in windward Black Forest areas resulting from too much rain converted into runoff in the model and the forcing data which was too dry. Differences in the surface fluxes are attributed to a wrong soil type and an inappropriate land use type. The atmospheric water vapour content was overestimated in the valley and at windward sites, but underestimated at higher levels, probably because thermally induced circulation systems were not represented well by the model. In part 2, the impact of multi-layer soil-vegetation-atmosphere transfer models (SVATs) and the prescribed soil type distribution is discussed. The use of the refined land-surface scheme VEG3D partially reduces the precipitation biases particularly at the highly vegetated windward and mountain crests of the Black Forest. The authors state that the correct representation of the soil type near the surface and the soil types below are highly relevant for the simulation of soil water content and soil temperature which result in adequate surface turbulent fluxes and consequently improved simulation of precipitation in regional climate models.

\section{References}

Aoshima, F., A. Behrendt, H.-S. BAUER, V. WUlfMEYer, 2008: Statistics of convection initiation by use of the Meteosat Rapid Scan Service during the Convection and Orographically induced Precipitation Study. - Meteorol. Z. 17, 921-930. DOI: $10.1127 / 0941-2948 / 2008 / 0337$.

Barthlott, C., J.W. Schipper, N. Kalthoff, B. Adler, C. Kottmeier, A.M. Blyth, S. Mobbs, 2010: Model representation of boundary-layer convergence triggering deep convection over complex terrain: A case-study from COPS. - Atmos. Res. 95, 172-185. DOI: 10.1016/j.atmosres.2009.02.010.

Barthlott, C., R. Burton, D. Kirshbaum, K. HANLEY, R. Richard, J.P. Chaboureau, J. TRENTMANN, B. Kern, H.-S. Bauer, T. Schwitalla, C. Keil, Y. Seity, A. Gadian, A.M. Blyth, S. Mobbs, C. Flamant, J. Handwerker, 2011: Initiation of deep convection at marginal instability in an ensemble of mesoscale models: A case-study from COPS. - Quart. J. Roy. Meteor. Soc. 137, 118-136. DOI: 10.1002/qj.707.

Bauer, H.-S., T. Weusthoff, M. Dorninger, V. Wulfmeyer, T. Gorgas, M. Arpagaus, T. Schwitalla, K. WARRACH-SAGI, 2011a: Predictive skill of the D-PHASE multi-model ensemble in the COPS region. - Quart. J. Roy. Meteor. Soc. 137, 287-305. DOI: 10.1002/qj.715.

BAUER, H.-S., F. ZUS, V. WULFMEYER, T. SCHWITALLA, M. GRZESCHIK, 2011b: Operational assimilation of GPS slant path delay measurements into the MM5 4DVAR system. - Tellus A 63, 263-282. DOI: 10.1111/j.1600-0870.2010.00489.x. 
Behrendt, A., V. Wulfmeyer, A. Riede, G. Wagner, S. Pal, H. BAuer, M. Radlach, F. Späth, 2009: 3-Dimensional observations of atmospheric humidity with a scanning differential absorption lidar. - Proc. SPIE 7475, 74750L. DOI: $10.1117 / 12.835143$.

Behrendt, A., S. Pal, F. Aoshima, M. Bender, A. Blyth, U. Corsmeier, J. Cuesta, G. Dick, M. Dorninger, C. Flamant, P. Di Girolamo, T. Gorgas, Y. Huang, N. Kalthoff, S. Khodayar, H. Mannstein, K. Träumner, A. WIESER, V. WULFMEYER, 2011: Observation of convection initiation processes with a suite of state-of-the-art research instruments during COPS IOP8b. - Quart. J. Roy. Meteor. Soc. 137, 81-100. DOI: 10.1002/qj.758.

Bennett, L.J., A.M. Blyth, R.R. Burton, A.M. Gadian, T.M. Weckwerth, A. BehrendtA, P. Di Girolamo, M. DORNINGER, S.-J. LOCK, V.H. SMITH, S.D. MOBBS, 2011: Initiation of convection over the Black Forest mountains during COPS IOP15a. - Quart. J. Roy. Meteor. Soc 137, 176-189. DOI: 10.1002/qj.760.

Bhawar, R., P. Di Girolamo, D. Summa, C. Flamant, D. Althausen, A. Behrendt, C. Kiemle, P. Bosser, M. Cacciani, C. Champollion, T. Di Iorio, R. Engelmann, C. Herold, S. PA, A. Riede, M. Wirth, V. Wulfmeyer, 2011: The water vapour intercomparison effort in the framework of the Convective and Orographically-induced Precipitation Study: Airborne-to-ground-based and airborne-to airborne lidar systems. - Quart. J. Roy. Meteor. Soc 137, 325-347. DOI: 10.1002/qj.697.

Bielli, S., M. Grzeschik, E. Richard, C. Flamant, C. Champollion, C. Kiemle, M. Dorninger, P. Brousseau, 2012: Assimilation of water vapour airborne lidar observations: Impact study on the COPS precipitation forecasts. - Quart. J. Roy. Meteor. Soc 138, 1652-1667.

BurTON, R.R., A. GADIAN, A.M. BLYTh, S.D. MoBBS, 2013: Modelling isolated deep convection: a case study from COPS. - Meteorol. Z. 22, 433-443. DOI: 10.1127/0941-2948/2013/0408.

Chaboureau, J.-P., E. Richard, J.-P. Pinty, C. Flamant, P. Di Girolamo, C. Kiemle, A. Behrendt, H. Chepfer, M. Chiriaco, V. WulfMeYer, 2011: Long-range transport of Saharan dust and its impact on precipitation forecast over western Europe. - Q. J. Roy. Meteorol. Soc 137, 236-251. DOI: 10.1002/qj.719.

Corsmeier, U., N. Kalthoff, C. Barthlott, A. Behrendt, P. Di Girolamo, M. Dorninger, F. Aoshima, J. Handwerker, Ch. Kottmeier, H. Mahlke, St. Mobbs, G. Vaughan, J. Wickert, V. WulfmeYer, 2011: Processes driving deep convection over complex terrain: A multi-scale analysis of observations from COPS IOP 9c. - Quart. J. Roy. Meteor. Soc. 137, 137-155. DOI: 10.1002/qj.754.

Crewell, S., M. Mech, T. Reinhardt, C. Selbach, H.D. Betz, E. Brocard, G. Dick, E. O’Connor, J. Fischer, T. Hanisch, T. Hauf, A. Hünerbein, L. Delobbe, A. Mathes, G. Peters, H. Wernli, M. Wiegner, V. WulfmeYer, 2008: The general observation period 2007 within the priority program on quantitative precipitation forecasting: Concept and first results. - Meteorol. Z. 17, 849-866.

Davis, J., C. Collier, F. Davies, R. Burton, G. Pearson, P. Di Girolamo, 2013: Vertical Velocity Observed By Doppler Lidar During COPS - A Case Study With A Convective Rain Event. - Meteorol. Z. 22, 463-470. DOI: 10.1127/09412948/2013/0411.

DORnINGER, M., T. GORGAS, 2010: 'Using the JDC (Joint D-PHASE COPS) observational data set for high-resolution analysis and ensemble analysis'. - In: Proceedings of 14th AMS Conference on Mountain Meteorology, Lake Tahoe, USA, 30 August-3 September. - Amer. Meteor. Soc, Boston.

Dorninger, M., T. GoRgas, 2013: Comparison of NWP-model chains by using novel verification methods. - Meteorol. Z. 22, 373-393. DOI: 10.1127/0941-2948/2013/0488.

Eigenmann, R., N. Kalthoff, T. Foken, M. Dorninger, M. Kohler, D. Legain, G. Pigeon, B. Piguet, D. SCHÜtTEMEYER, O. TRAULlED, 2011: Surface energy balance and turbulence network during COPS. - Quart. J. Roy. Meteor. Soc. 137, 57-69. DOI: 10.1002/qj.704.

GORGAS, T., M. DORNINGER, 2012a: Concepts for a pattern-oriented analysis ensemble based on observational uncertainties. - Quart. J. Roy. Meteor. Soc. 138, 769-784. DOI: 10.1002/qj.949.

GORGAS, T., M. DORNINGER, 2012b: Quantifying verification uncertainty by reference data variation. - Meteorol. Z. 21, 259-277. DOI: 10.1127/0941-2948/2012/0325.

HAGEN, M., J. VAN BAELEN, E. RICHARD, 2011: Influence of the wind profile on the initiation of convection in mountainous terrain. - Quart. J. Roy. Meteor. Soc. 137, 224-235. DOI: 10.1002/qj.784.

Hauck, C., C. Barthlott, L. Krauss, N. Kalthoff, 2011: Soil moisture variability and its influence on convective precipitation over complex terrain. - Quart. J. Roy. Meteor. Soc. 137, 42-56. DOI: 10.1002/qj.766.

Hense, A., V. WulfmeYeR, 2008: The German Priority Program SPP1167 'Quantitative Precipitation Forecast'. - Meteorol. Z. 17, 703-705.

Huang, Y., A.M. Blyth, P.R.A. Brown, R. Cotton, J. Crosier, K.N. Bower, M.W. Gallagher, H. Jones, A.M. Gadian, T.W. Choularton, J. Cardwell, H. CoE, S.D. Mobbs, M. Hagen, 2011: Development of ice particles in convective clouds observed over the Black Forest mountains during COPS. - Quart. J. Roy. Meteor. Soc. 137, $275-286$. DOI: $10.1002 /$ qj.749. 
Kalthoff, N., B. Adler, C. Barthlott, U. Corsmeier, S.D. Mobbs, S. Crewell, K. Träumner, C. Kottmeier, A. WIESER, V. SMITH, 2009: The impact of convergence zones on the initiation of deep convection: A case study from COPS. - Atmos. Res. 93, 680-694. DOI: 10.1016/j.atmosres.2009.02.010.

Kalthoff, N., M. Kohler, C. Barthlott, S. Mobbs, U. Corsmeier, B. Adler, K. Träumner, T. Foken, R. EIGenmanN, L. KrausS, S. KhODAYAR, P. Di Girolamo, 2011: The dependence of convection-related parameters on surface and boundary-layer conditions over complex terrain. - Quart. J. Roy. Meteor. Soc. 137, 70-80. DOI: 10.1002/ qj.686.

Kalthoff, N., K. Träumner, B. Adler, S. Späth, A. Behrendt, A. Wieser, J. Handwerker, F. Madonna, V. WULFMEYER, 2013: Dry and moist convection in the boundary layer over the Black Forest - a combined analysis of in situ and remote sensing data. - Meteorol. Z. 22, 445-461. DOI: 10.1127/0941-2948/2013/0417.

KHODAYAR, S., G. SCHÄDLER, 2013: The impact of soil moisture variability on seasonal convective precipitation simulations. Part II: sensitivity to land-surface models and prescribed soil type distributions. - Meteorol. Z. 22, 507-526. DOI: 10.1127/ 0941-2948/2013/0431.

KHODAyAR, S., N. KAlthOFF, G. SCHÄDLER, 2013: The impact of soil moisture variability on seasonal convective precipitation simulations. Part I: validation, feedbacks, and realistic initialisation. - Meteorol. Z. 22, 489-505. DOI: 10.1127/0941-2948/2013/0403.

Kiemle, C., M. Wirth, A. Fix, S. Rahm, U. Corsmeier, P. Di Girolamo, 2011: Latent heat flux measurements over complex terrain by airborne water vapour and wind lidars. - Quart. J. Roy. Meteor. Soc. 137, 190-203. DOI: 10.1002/ qj. 757.

Kottmeier, C., N. Kalthoff, C. Barthlott, U. Corsmeier, J. Van Baelen, A. Behrendt, R. Behrendt, A. Blyth, R. Coulter, S. Crewell, P. Di Girolamo, M. Dorninger, C. Flamant, T. Foken, M. Hagen, C. Hauck, H. Holler, H. Konow, M. Kunz, H. Mahlke, S. Mobbs, E. Richard, R. Steinacker, T. Weckwerth, A. Wieser, 2008: Mechanisms initiating deep convection over complex terrain during COPS. - Meteorol. Z. 17, 931-948. DOI: 10.1127/ 0941-2948/2008/0348.

Labbouz, L., J. Van Baelen, F. Tridon, M. Reverdy, M. Hagen, M. Bender, G. Dick, T. Gorgas, C. Planche: Precipitation on the lee side of the Vosges Mountains: Multi-instrumental study of one case from the COPS campaign. - Meteorol. Z. 22, 413-432. DOI: 10.1127/0941-2948/2013/0413.

Masiello, G., C. Serio, T. Deleporte, H. Herbin, P. Di Girolamo, C. Champollion, A. Behrendt, P. Bosser, O. Bock, V. Wulfmeyer, M. Pommier, C. Flamant, C. Planche, W. Wobrock, A.I. Flossmann, F. Tridon, L. LABBOUZ, J. VAN BAELEN, 2013: Comparison of IASI water vapour products over complex terrain with COPS campaign data. - Meteorol. Z. 22, 471-487. DOI: 10.1127/0941-2948/2013/0430.

Planche, C., W. Wobrock, A.I. Flossmann, F. Tridon, L Labbouz, J. Van Baelen, 2013: Small scale topography influence on the formation of three convective systems observed during COPS over the Vosges Mountains. - Meteorol. Z. 22, 395-411. DOI: 10.1127/0941-2948/2013/0402.

RADlACH, M., A. BEHRENDT, V. WulfMEYER, 2008: Scanning rotational Raman lidar at 355 nm for the measurement of tropospheric temperature fields. - Atmos. Chem. Phys. 8, 159-169. DOI: 10.5194/acp-8-159-2008.

Richard, E., J.-P. Chaboureau, C. Flamant, C. Champollion, M. Hagen, K. Schmidt, C. Kiemle, C. Corsmeier, C. BARTHLOTT, 2011: Forecasting summer convection over the Black Forest: A case-study from the COPS experiment. - Quart. J. Roy. Meteor. Soc. 137, 101-117. DOI: 10.1002/qj.710.

Richard, E., C. Flamant, F. Bouttier, J. Van Baelen, C. Champollion, S. Argence, J. Arnault, C. Barthlott, A. Behrendt, P. Bosser, P. Brousseau, J.-P. Chaboureau, U. Corsmeier, J. Cuesta, P. Di Girolamo, M. Hagen, C. Kottmeier, P. Limnaios, F. Masson, G. Pigeon, Y. Pointin, Y. Seity, V. WulfmeYer, 2009: La campagne COPS: Initiation et cycle de vie de la convection en region montagneuse. - La Météorologie 64, 32-42.

Rotach, M.W., P. Ambrosetti, F. Ament, C. Appenzeller, M. Arpagaus, H.-S. Bauer, A. Behrendt, F. Bouttier, A. Buzzi, M. Corazzo, S. DaVolio, M. Denhard, M. Dorninger, L. Fontannaz, J. Frick, F. Fundel, U. GERMAnN, T. Gorgas, C. HegG, A. Hering, C. Keil, M.A. Liniger, C. Marsigli, R. Mctaggart-Cowan, A. Montaini, K. Mylne, R. Ranzi, E. Richard, A. Rossa, A. Santos-Muñoz, C. Schär, Y. Seity, M. Staudinger, M. Stoll, H. Volkert, A. WAlser, Y. WANG, J. Wehrhahn, V. WulfmeYer, M. ZAPPA 2009a. MAP D-PHASE: Real-time demonstration of weather forecast quality in the Alpine region. - Bull. Amer. Meteor. Soc. 90, 1321-1336. DOI: 10.1175/ 2009BAMS2776.1.

Rotach, M.W., P. Ambrosetti, F. Ament, C. Appenzeller, M. Arpagaus, H.-S. Bauer, A. Behrendt, F. Bouttier, A. Buzzi, M. Corazzo, S. DaVolio, M. Denhard, M. Dorninger, L. Fontannaz, J. Frick, F. Fundel, U. GERmann, T. Gorgas, C. Hegg, A. Hering, C. Keil, M.A. Liniger, C. Marsigli, R. Mctaggart-Cowan, A. Montaini, K. Mylne, R. Ranzi, E. Richard, A. Rossa, A. Santos-Muñoz, C. Schär, Y. Seity, M. Staudinger, M. Stoll, H. Volkert, A. WALSER, Y. WANG, J. WeHrhahn, V. WulfMEYER, M. ZAPPA, 2009b: Supplement: Additional applications of the D-PHASE data sets. - Bull. Amer. Meteor. Soc. 90 (electronic supplement), 28-32.

SCHÄFler, A., A. DÖRnBrack, C. KIEMLE, S. RAHM, M. WIRTH, 2010: Tropospheric water vapor transport as determined from airborne lidar measurements. - J. Atmos. Ocean. Technol. 27, 2017-2030. DOI: 10.1175/2010JTECHA1418.1. 
Schwitalla, T., H.-S. BAUER, V. WULFMEYER, 2011: High-resolution simulation over central Europe using GPS-ZTD observations with WRF 3DVAR: A case-study of COPS IOP9c. - Quart. J. Roy. Meteor. Soc. 137, 156-175. DOI: 10.1002/ qj. 721.

VAn Baelen, J., M. Reverdy, F. Tridon, L. LabbouZ, G. Dick, M. Bender, M. Hagen, 2011: On the relationship between water vapour field evolution and the life cycle of precipitation systems. - Quart. J. Roy. Meteor. Soc. 137, 204-223. DOI: 10.1002/qj.785.

Wagner, G., A. Behrendt, V. Wulfmeyer, F. Späth, M. Schiller, 2013: High-power Ti:sapphire laser at $820 \mathrm{~nm}$ for scanning ground-based water-vapor differential absorption lidar. - Appl. Opt. 52, 2454-2469. DOI: 10.1364/ AO.52.002454.

Weckwerth, T.M., J.W. Wilson, M. HAgen, T.J. EMERSON, L. GREBE, 2011: Radar climatology of the COPS region. - Quart. J. Roy. Meteor. Soc. 137, 31-41. DOI: 10.1002/qj.747.

WulfMeYer, V., A. Behrendt (Eds.), 2007: COPS field report. - available at www.uni-hohenheim.de/cops.

Wulfmeyer, V., A. Behrendt, H.S. Bauer, C. Kottmeier, U. Corsmeier, A. Blyth, G. Craig, U. Schumann, M. Hagen, S. Crewell, P. Di Girolamo, C. Flamant, M. Miller, A. Montani, S. Mobbs, E. Richard, M.W. Rotach, M. Arpagaus, H. Russchenberg, P. Schlüssel, M. König, V. GÄrtner, R. Steinacker, M. Dorninger, D. Turner, T. WECKWERTH, A. Hense, C. SIMMER, 2008: The Convective and Orographically induced Precipitation Study: A research and development project of the World Weather Research Program for improving quantitative precipitation forecasting in low-mountain regions. - Bull. Amer. Meteor. Soc. 89, 1477-1486. DOI: 10.1175/2008BAMS2367.1.

Wulfmeyer, V., A. Behrendt, C. Kottmeier, U. Corsmeier, C. BArthlott, G.C. Craig, M. Hagen, D. Althausen, F. Aoshima, M. Arpagaus, H.-S. Bauer, L. Bennett, A. Blyth, C. Brandau, C. Champollion, S. Crewell, G. Dick, P. Di Girolamo, M. Dorninger, Y. Dufournet, R. Eigenmann, R. Engelmann, C. Flamant, T. Foken, T. Gorgas, M. Grzeschik, J. Handwerker, C. Hauck, H. Höller, W. Junkermann, N. Kalthoff, C. Kiemle, S. Klink, M. König, L. Krauss, C.N. Long, F. Madonna, S. Mobbs, B. Neininger, S. Pal, G. Peters, G. Pigeon, E. Richard, M.W. Rotach, H. Russchenberg, T. Schwitalla, V. Smith, R. Steinacker, J. Trentmann, D.D. Turner, J. van Baelen, S. Vogt, H. Volkert, T. WeckWerth, H. Wernli, A. Wieser, M. Wirth, 2011: The Convective and Orographically-induced Precipitation Study (COPS): The scientific strategy, the field phase, and research highlights. - Quart. J. Roy. Meteor. Soc. 137, 3-30. DOI: 10.1002/qj.752.

Yan, X., V. DucrocQ, G. Jaubert, P. Brousseau, P. Poli, C. Champollion, C. Flamant, K. Boniface, 2009: The benefit of GPS zenith delay assimilation to high-resolution quantitative precipitation forecasts: A case-study from COPS IOP 9. - Quart. J. Roy. Meteor. Soc. 135, 1788-1800.

ZUS, F., M. GRZESCHIK, H.-S. BAUER, V. WULFMEYER, 2008: Design and optimization of the IPM GPS slant path 4DVAR system. - Meteorol. Z. 17, 867-885. 